\title{
SCIDiC
}

\author{
International Journal of Dentistry and Oral Science (IJDOS) \\ ISSN: 2377-8075
}

\section{Prevalence of Dental Fluorosis amongst Young Adults and Adolescents in Chennai}

Research Article

Anisha A Mahtani ${ }^{1}$, Arthi Balasubramaniam ${ }^{2 *}$, Ravindrakumar Jain ${ }^{3}$

${ }^{1}$ Saveetha Dental College and Hospital, Saveetha Institute of Medical and Technical Sciences, Saveetha University, Chennai 600077, Tamil Nadu, India. ${ }^{2}$ Senior Lecturer, Department of Public Health Dentistry, Saveetha Dental College and Hospital, Saveetha Institute of Medical and Technical Sciences, Saveetha University, Chennai 600077, Tamil Nadu, India.

${ }^{3}$ Reader, Department of Orthodontics, Saveetha Dental College and Hospital, Saveetha Institute of Medical and Technical Sciences, Saveetha University, Chennai 600077, Tamil Nadu, India.

Abstract

Many studies have been conducted to evaluate the prevalence of dental fluorosis in different states and countries. The purpose of this study is to evaluate the prevalence of dental fluorosis amongst young adults and adolescents in Chennai. In this retrospective study, case records of 564 patients of all ages who were diagnosed with dental fluorosis upon reporting to the University hospital in Chennai were reviewed. About 90 patient records of age group 15-20 years (adolescents) and 21-25 years (adults) were retrieved and analysed. Descriptive statistics and tests of association were done at a $\mathrm{p}$ value $<0.05$. The results revealed the prevalence of dental fluorosis in adolescents was $4.07 \%$ and $11.8 \%$ amongst young adults. The study found no significant association between the age and prevalence of dental fluorosis $(\mathrm{p}=0.998)$ or between gender and prevalence of dental fluorosis $(\mathrm{p}=0.386)$. Age and gender has no influence on prevalence of dental fluorosis.

Keywords: Adolescents; Dean’s Fluorosis Index; Dental Fluorosis; Young Adults.

\section{Introduction}

Dental fluorosis is defined as the hypomineralization of enamel that occurs due to the ingestion of excessive levels of fluoride during enamel formation. Drinking water is a major source of fluoride in India. It affects the population of 20 states in India [1] and about 62 million Indians suffer from dental, skeletal and non-skeletal fluorosis. Fluorosis is endemic in most of the states in India due to its tropical climate. Dental fluorosis requires aesthetic treatment since it affects the quality of life. In mild cases of fluorosis, tooth bleaching can be done, in moderate cases, enamel microabrasion is required and in severe cases, composite fillings, micro abrasion, crowns and veneers can be used [2-7].

Previous researchers found that the source of water till eight years of age was significantly associated with the prevalence of dental fluorosis and adolescents who drank water from a hand pump were more prone [8]. Prevalence of dental fluorosis in Kerala [9], Gujarat [10], Udaipur [11] and Haryana [12] were found to be 16.8 $\%, 17.7 \%, 36.3 \%$ and $92.7 \%$ respectively. In Greater Noida [13] prevalence of fluorosis was $21 \%$ but the very mild form of dental fluorosis was more prevalent in adolescents with $27.6 \%$.

In a study to assess the groundwater fluoride concentration in Kanchipuram,Tamil Nadu, it was found that the fluoride concentration ranged between 0.05-1.04 mg/l. In Madurai, Tamil Nadu, fluoride contents in all samples ranged between $0.12-1.2 \mathrm{mg} / \mathrm{l}$, which is less than the optimum range of $1.5 \mathrm{mg} / \mathrm{L}$, as recommended by WHO. Hence, fluoride contents in all the samples exhibit their suitability for drinking [14-16]. But districts in Tamil Nadu such as Salem, Dharmapuri and Krishnagiri have $>3 \mathrm{ppm}$ of fluoride in drinking water. Previously our team has a rich experience in working on various research projects across multiple disciplines [17-31]. Now the growing trend in this area motivated us to pursue this project.

Since existing studies show a high prevalence of fluorosis in other states in India, we evaluate the prevalence of fluorosis among adolescents and young adults in Chennai.

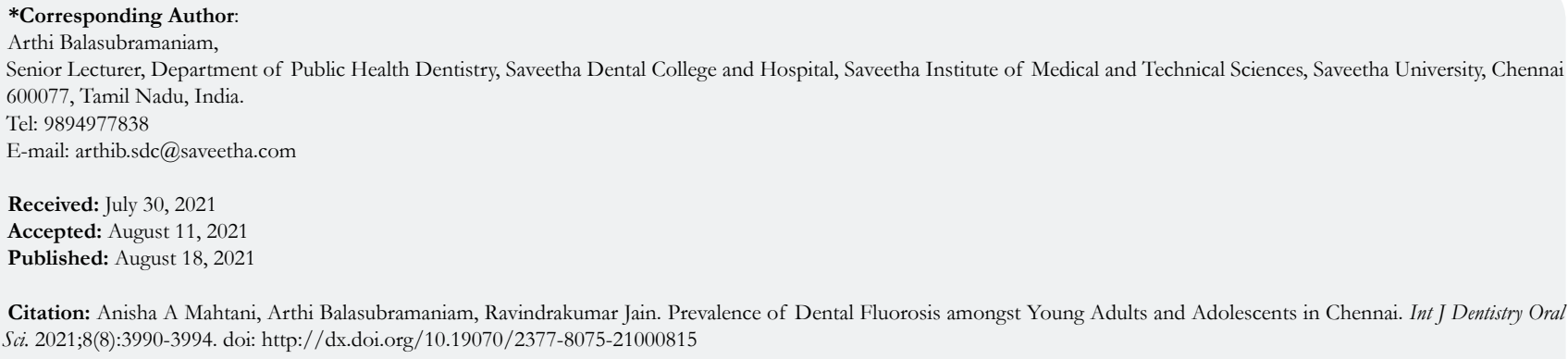

Copyright: Arthi Balasubramaniam ${ }^{\circ} 2021$. This is an open-access article distributed under the terms of the Creative Commons Attribution License, which permits unrestricted use, distribution and reproduction in any medium, provided the original author and source are credited. 


\section{Materials and Methods}

\section{Study design and Study setting:}

The present study was conducted in the author's University hospital in Chennai to evaluate the prevalence of dental fluorosis amongst young adults and adolescents from June 2019 to March 2020. The retrospective study was done by reviewing $86,000 \mathrm{pa}-$ tient records with signed informed consent from University hospital.

\section{Permission:}

Prior permission was obtained from the University to utilize the data of case records for data analysis.

\section{Sampling:}

Of 86,000 case records, 564 consecutive case records of patients with dental fluorosis were retrieved. No gender restriction was placed. On subjecting to selection criteria about 90 case records of patients of age group 15-20 years and 21-25 years were sorted. An effort was taken to verify dental fluorosis using clinical photographs. The study contained regional data generalised to the South Indian population.

\section{Data Collection:}

The retrospective study involved 90 patients of 15-25 years who were diagnosed with dental fluorosis. The data on severity of dental fluorosis was measured using Dean's Fluorosis Index upon reporting to the dental hospital by Trendley H Dean in 1942. They were categorised into Questionable (0.5), Very mild (1), Mild (2), Moderate (3), Severe (4). A calibrated single examiner reviewed the score and tabulated them. Data on age and gender were retrieved from the case records.

\section{Statistical Analysis:}

The collected data was validated, tabulated and analysed with Statistical Package for Social Sciences for Windows, version 20.0 (SPSS Inc., Chicago, IL, USA). Frequency distribution of severity of dental fluorosis among adults and adolescents was calculated. Pearson's chi-square association was used to test associations between age, gender and dental fluorosis. P value $<0.05$ was considered statistically significant.

\section{Results \& Discussion}

The current study was conducted to evaluate the prevalence of dental fluorosis among adolescents and young adults in Chennai from June 2019 to March 2020. Among the 90 case records of patients $74.4 \%$ were adults of age group $21-25$ years and $25.5 \%$ were adolescents of age group 15-20 years [Figure 1]. Males $(71.1 \%)$ were more predominant in the study population than females $(28.9 \%)$ [Figure 2].

The prevalence of dental fluorosis in adults was found to be $11.8 \%$ and $4.07 \%$ in adolescents. It was found to be higher among the young adults compared to adolescents. This statement was contradicted by Shruti MN [32] who found the prevalence to be higher in children and adolescents rather than adults.

The prevalence of the severity of fluorosis, based on the Deans Fluorosis Index in the 15-20 year age group was 8.6\% with Questionable (Grade 0.5); $17.3 \%$ with very mild fluorosis (Grade 1); $47.8 \%$ with mild fluorosis (Grade 2); $21.7 \%$ with moderate fluorosis (Grade 3) and $4.3 \%$ of patients with severe fluorosis (Grade 4). In the 21-25 year age group the prevalence was $7.4 \%$ with Questionable (Grade 0.5); $14.9 \%$ with very mild fluorosis (Grade 1); $50.7 \%$ with mild fluorosis (Grade 2); $22.3 \%$ with moderate fluorosis (Grade 3) and 4.4\% of patients with severe fluorosis (Grade 4). The present study did not find a statistically significant association between the prevalence of dental fluorosis and age of

Figure 1. Bar chart depicting the distribution of age of patients in percentage. $\mathrm{X}$ axis represents the age of patients and $\mathrm{Y}$ axis represents the number of patients with dental fluorosis. Most of the patients were young adults $(74.4 \%)$.

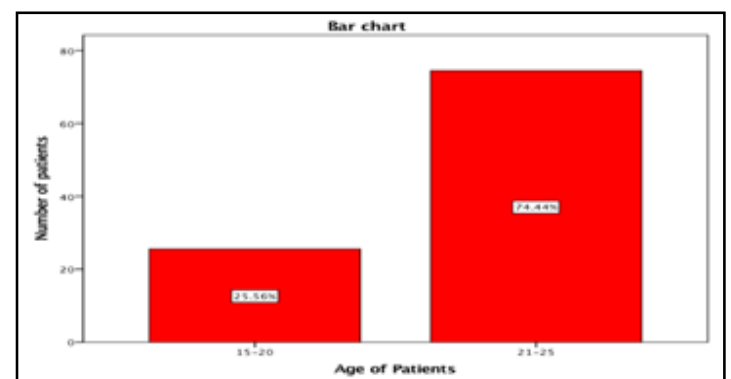

Figure 2. Bar chart depicting the distribution of gender of patients in percentage. $\mathrm{X}$ axis represents the gender of patients and $\mathrm{Y}$ axis represents the number of patients with dental fluorosis. Males $(71.1 \%)$ predominated the study population.

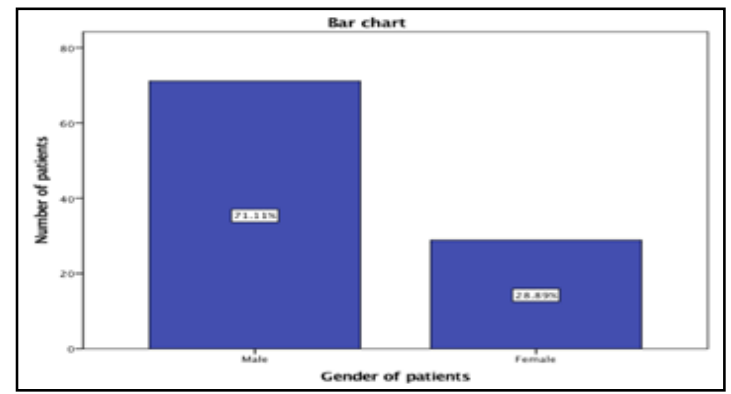


Figure 3. Bar chart depicting the association between dental fluorosis and age groups. $\mathrm{X}$ axis represents the age of patients and $\mathrm{Y}$ axis represents the number of patients reviewed for Dean's Fluorosis Index score. Association between dental fluorosis and age groups was done using Chi square test and it was not significant. Chi square association test (Fisher's exact test value $=0.131 ; \mathrm{p}$ value $=0.988 ;$ not significant). Age has no role in the severity of dental fluorosis.

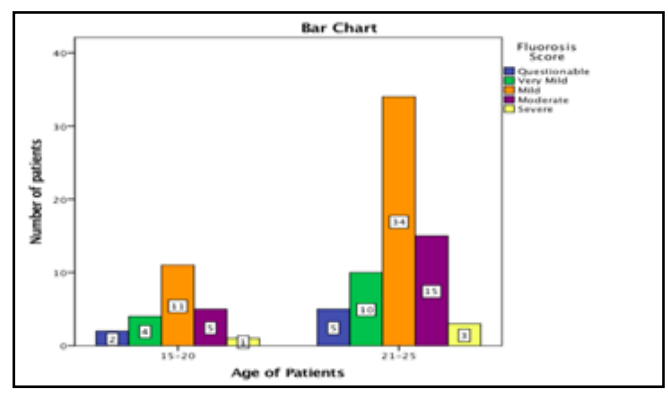

Figure 4: Bar chart depicting the association between dental fluorosis based on gender. $X$ axis represents the Gender of patients and $Y$ axis represents the number of patients reviewed for Dean's Fluorosis Index score. Association between dental fluorosis and gender was done using Chi square test and it was not significant. Chi square association test (Fisher's exact test value $=0.349 ; \mathrm{p}$ value $=0.555 ;$ not significant). Gender has no role in the severity of fluorosis.

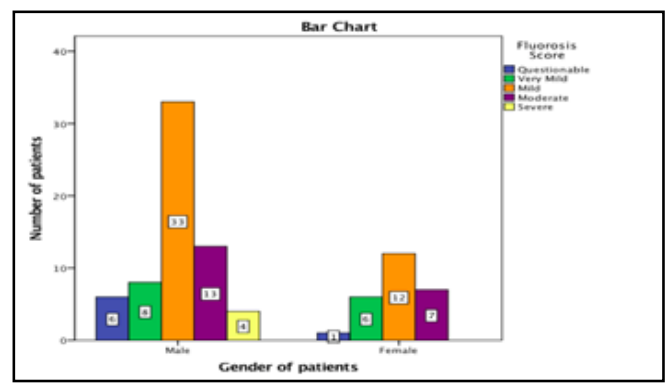

the patients $(\mathrm{p}=0.998)$ [Figure 3] This statement is supported by Arif et al., [33] who found that the prevalence varied significantly with age. However, a study conducted by Sukhabogi et al [(34)] disagreed with this statement.

In accordance with gender, overall, $71.1 \%$ of males and $28.9 \%$ of females were diagnosed with dental fluorosis. The prevalence of the severity of fluorosis, based on the Deans Fluorosis Index amongst the males was 9.3\% with Questionable (Grade 0.5); $12.5 \%$ with very mild fluorosis (Grade 1 ); $51.5 \%$ with mild fluorosis (Grade 2); 20.3\% with moderate fluorosis (Grade 3) and $6.2 \%$ of patients with severe fluorosis (Grade 4). Among the females, the prevalence was 3.8\% with Questionable (Grade 0.5); $23 \%$ with very mild fluorosis (Grade 1); $46.1 \%$ with mild fluorosis (Grade 2) and 26.9\% with moderate fluorosis (Grade 3). Severe fluorosis (Grade 4) was not seen in females. This study found no statistically significant association between gender and prevalence of dental fluorosis $(p=0.555)$. [Figure 4] This statement was supported by Sarvaiya et al [(35)] who found no significant difference amongst both genders and the prevalence of fluorosis. It was also supported by many other studies that found a non-significant association [32-37]. In fact, in the Universally available literature, no tendency towards developing dental fluorosis was reported by either of the genders[13, 38-40].

In the present study, mild form of dental fluorosis (Grade 2) was seen in $47.8 \%$ of the adolescents as the most predominant type. Very mild type of dental fluorosis (Grade 1) was seen in $27.6 \%$ of the adolescents as the predominant type in the study by Chaudhury.M et al., [13]. Milder forms of fluorosis were more common than its severe forms. This finding was supported by studies done by Srivatsava et al., [41] and Naidu et al., [8]. Dental fluorosis is endemic in 150,000 villages in India [42-46].
A report described the interexaminer reliability achieved using Dean's Index in a study of dental fluorosis. Using Dean's definition of fluorosis, agreement on the presence or absence of fluorosis ranged from 92 to 97 percent and therefore the respective kappa values ranged from 0.75 to 0.94 . Examiners showed good to excellent agreement beyond chance in the use of this index. Hence the index is very reliable to review dental fluorosis [47]. Our institution is passionate about high quality evidence based research and has excelled in various fields [48-58]. We hope this study adds to this rich legacy.

Limitations of the study include a restricted population group due to it being a single centered study. Another limitation includes the data only being collected for a period of 10 months. Also, since it is a retrospective study based on case records, the cases could not be reviewed clinically and we relied on the uploaded scoring of the Dean's fluorosis index by dentists in the hospital. However these scores were all reviewed by a single calibrated examiner with the help of clinical photographs as well. Future scope of the study could be improved by conducting a prospective cohort study considering the geographic location.

\section{Conclusion}

The prevalence of dental fluorosis is not dependent on the age and gender of the patients. The Mild form of dental fluorosis was found to be the most prevalent type in both adults and adolescents.

\section{References}

[1]. Majumdar KK. Health impact of supplying safe drinking water containing fluoride below permissible level on flourosis patients in a fluorideendemic rural area of West Bengal. Indian J Public Health. 2011 OctDec;55(4):303-8.Pubmed PMID: 22298140. 
[2]. Prabakar J, John J, Srisakthi D. Prevalence of dental caries and treatment needs among school going children of Chandigarh. Indian J Dent Res. 2016 Sep-Oct;27(5):547-552.Pubmed PMID: 27966516.

[3]. Prabakar J, John J, Arumugham IM, Kumar RP, Srisakthi D. Comparative evaluation of retention, cariostatic effect and discoloration of conventional and hydrophilic sealants-A single blinded randomized split mouth clinical trial. Contemp. Clin. Dent. 2018 Sep;9(Suppl 2):S233.

[4]. Samuel SR, Acharya S, Rao JC. School Interventions-based Prevention of Early-Childhood Caries among 3-5-year-old children from very low socioeconomic status: Two-year randomized trial. J Public Health Dent. 2020 Jan;80(1):51-60.Pubmed PMID: 31710096

[5]. Mathew MG, Samuel SR, Soni AJ, Roopa KB. Evaluation of adhesion of Streptococcus mutans, plaque accumulation on zirconia and stainless steel crowns, and surrounding gingival inflammation in primary molars: randomized controlled trial. Clin Oral Investig. 2020 Sep;24(9):3275-3280.Pubmed PMID: 31955271

[6]. Khatri SG, Madan KA, Srinivasan SR, Acharya S. Retention of moisturetolerant fluoride-releasing sealant and amorphous calcium phosphate-containing sealant in 6-9-year-old children: A randomized controlled trial. J Indian Soc Pedod Prev Dent. 2019 Jan-Mar;37(1):92-98.Pubmed PMID: 30804314.

[7]. Prabakar J, John J, Arumugham IM, Kumar RP, Sakthi DS. Comparative Evaluation of the Viscosity and Length of Resin Tags of Conventional and Hydrophilic Pit and Fissure Sealants on Permanent Molars: An In vitro Study. Contemp Clin Dent. 2018 Jul-Sep;9(3):388-394.Pubmed PMID: 30166832.

[8]. Naidu GM, Rahamthullah SA, Kopuri RK, Kumar YA, Suman SV, Balaga RN. Prevalence and self perception of Dental Fluorosis among 15 year old school children in Prakasham district of south India. J Int Oral Health. 2013 Dec;5(6):67-71.Pubmed PMID: 24453447.

[9]. Gopalakrishnan P, Vasan RS, Sarma PS, Nair KS, Thankappan KR. Prevalence of dental fluorosis and associated risk factors in Alappuzha district, Kerala. Natl Med J India. 1999 May-Jun;12(3):99-103.Pubmed PMID: 10492580.

[10]. Susheela AK. A treatise on fluorosis. New Delhi: FR\&RDF. 2007.

[11]. Dhar V, Jain A, Van Dyke TE, Kohli A. Prevalence of gingival diseases, malocclusion and fluorosis in school-going children of rural areas in Udaipur district. J Indian Soc Pedod Prev Dent. 2007 Apr-Jun;25(2):103-5.Pubmed PMID: 17660647.

[12]. DAHIYA S, KAUR A, JAIN N. Prevalence of fluorosis among school children in rural area, district Bhiwani: A case study. Indian J Environ Health. 2000;42(4):192-5.

[13]. Chaudhry M, Prabhakar I, Gupta B, Anand R, Sehrawat P, Thakar SS. Prevalence of dental fluorosis among adolescents in schools of Greater Noida, Uttar Pradesh. J. Indian Assoc. Public Health Dent. 2017 Jan 1;15(1):36.

[14]. Kumar RP, Vijayalakshmi B. Assessment of fluoride concentration in ground water in Madurai district, Tamil Nadu, India. Res J Pharm Technol. 2017;10(1):309-10.

[15]. Kumar RP, Preethi R. Assessment of water quality and pollution of Porur, Chembarambakkam and Puzhal Lake. Res J Pharm Technol. 2017;10(7):2157-9.

[16]. Saravanan S, Kalyani C, Vijayarani M, Jayakodi P, Felix A, Nagarajan S, et al. Prevalence of dental fluorosis among primary school children in rural areas of chidambaram taluk, cuddalore district, Tamil Nadu, India. Indian J Community Med. 2008 Jul;33(3):146-50.Pubmed PMID: 19876473.

[17]. Jain AR. Prevalence of partial edentulousness and treatment needs in rural population of South India. World J Dent. 2017 Jun;8(3):213-7.

[18]. Varghese SS, Ramesh A, Veeraiyan DN. Blended Module-Based Teaching in Biostatistics and Research Methodology: A Retrospective Study with Postgraduate Dental Students. J Dent Educ. 2019 Apr;83(4):445-450.Pubmed PMID: 30745352

[19]. Ashok V, Ganapathy D. A geometrical method to classify face forms. J Oral Biol Craniofac Res. 2019 Jul 1;9(3):232-5.

[20]. Padavala S, Sukumaran G. Molar incisor hypomineralization and its prevalence. Contemp Clin Dent. 2018 Sep;9(Suppl 2):S246-50.

[21]. Ke Y, Al Aboody MS, Alturaiki W, Alsagaby SA, Alfaiz FA, Veeraraghavan VP, et al. Photosynthesized gold nanoparticles from Catharanthus roseus induces caspase-mediated apoptosis in cervical cancer cells (HeLa). Artif Cells Nanomed Biotechnol. 2019 Dec;47(1):1938-1946.Pubmed PMID: 31099261.

[22]. Ezhilarasan D. Oxidative stress is bane in chronic liver diseases: Clinical and experimental perspective. Arab J Gastroenterol. 2018 Jun;19(2):56-64.Pubmed PMID: 29853428.

[23]. Krishnan RP, Ramani P, Sherlin HJ, Sukumaran G, Ramasubramanian A, Jayaraj G, et al. Surgical Specimen Handover from Operation Theater to Laboratory: A Survey. Ann Maxillofac Surg. 2018 Jul-Dec;8(2):234-238. Pubmed PMID: 30693238
[24]. Ezhilarasan D, Sokal E, Najimi M. Hepatic fibrosis: It is time to go with hepatic stellate cell-specific therapeutic targets. Hepatobiliary Pancreat Dis Int. 2018 Jun;17(3):192-197.Pubmed PMID: 29709350.

[25]. Pandian KS, Krishnan S, Kumar SA. Angular photogrammetric analysis of the soft-tissue facial profile of Indian adults. Indian J Dent Res. $2018 \mathrm{Mar}$ $1 ; 29(2): 137-43$

[26]. Ramamurthy JA, Mg V. Comparison of effect of Hiora mouthwash versus Chlorhexidine mouthwash in gingivitis patients: A clinical trial. Asian J Pharm Clin Res. 2018 Jul 7;11(7):84-8.

[27]. Gupta P, Ariga P, Deogade SC. Effect of Monopoly-coating Agent on the Surface Roughness of a Tissue Conditioner Subjected to Cleansing and Disinfection: A Contact Profilometric In vitro Study. Contemp Clin Dent. 2018 Jun;9(Suppl 1):S122-S126.Pubmed PMID: 29962776.

[28]. Vikram NR, Prabhakar R, Kumar SA, Karthikeyan MK, Saravanan R. Ball Headed Mini Implant. J Clin Diagn Res. 2017 Jan;11(1):ZL02-3.

[29]. Paramasivam A, Vijayashree Priyadharsini J, Raghunandhakumar S. N6adenosine methylation (m6A): a promising new molecular target in hypertension and cardiovascular diseases. Hypertens Res. 2020 Feb;43(2):153154.Pubmed PMID: 31578458.

[30]. Palati S, Ramani P, Shrelin HJ, Sukumaran G, Ramasubramanian A, Don $\mathrm{KR}$, et al. Knowledge, Attitude and practice survey on the perspective of oral lesions and dental health in geriatric patients residing in old age homes. Indian J Dent Res. 2020 Jan-Feb;31(1):22-25.Pubmed PMID: 32246676.

[31]. Samuel SR, Acharya S, Rao JC. School Interventions-based Prevention of Early-Childhood Caries among 3-5-year-old children from very low socioeconomic status: Two-year randomized trial. J Public Health Dent. 2020 Jan;80(1):51-60.Pubmed PMID: 31710096.

[32]. Shruthi MN, Anil NS. A comparative study of dental fluorosis and nonskeletal manifestations of fluorosis in areas with different water fluoride concentrations in rural Kolar. J Family Med Prim Care. 2018 NovDec;7(6):1222-1228.Pubmed PMID: 30613501.

[33]. Arif M, Husain I, Hussain J, Kumar S. Assessment of fluoride level in groundwater and prevalence of dental fluorosis in Didwana block of $\mathrm{Na}$ gaur district, Central Rajasthan, India. Int J Occup Environ Med. 2013 Oct; $4(4): 178-84$.

[34]. Sukhabogi JR, Parthasarathi P, Anjum S, Shekar B, Padma C, Rani A. Dental Fluorosis and Dental Caries Prevalence among 12 and 15-Year-Old School Children in Nalgonda District, Andhra Pradesh, India. Ann Med Health Sci Res. 2014 Sep;4(Suppl 3):S245-52.Pubmed PMID: 25364597.

[35]. Sarvaiya BU, Bhayya D, Arora R, Mehta DN. Prevalence of dental fluorosis in relation with different fluoride levels in drinking water among school going children in Sarada tehsil of Udaipur district, Rajasthan. J Indian Soc Pedod Prev Dent. 2012 Oct-Dec;30(4):317-22.Pubmed PMID: 23514684.

[36]. Choubisa SL, Choubisa L, Choubisa D. Osteo-dental fluorosis in relation to age and sex in tribal districts of Rajasthan, India. J Environ Sci Eng. 2010 Jul;52(3):199-204.Pubmed PMID: 21391391.

[37]. Michel-Crosato E, Biazevic MG, Crosato E. Relationship between dental fluorosis and quality of life: a population based study. Braz Oral Res. 2005 Apr-Jun;19(2):150-5.Pubmed PMID: 16292450.

[38]. Neralla M, Jayabalan J, George R, Rajan J, P SKM HA. Role of nutrition in rehabilitation of patients following surgery for oral squamous cell carcinoma. Int. j. res. pharm. sci. 2019 Oct 16;10(4):3197-203.

[39]. Pavithra RP, Jayashri P. Influence of naturally occurring phytochemicals on oral health. Res J Pharm Technol. 2019;12(8):3979-83.

[40]. Indiran MA. Awareness and attitude towards mass disaster and its management among house surgeons in a dental college and hospital in Chennai, India. Disaster Management and Human Health Risk V: Reducing Risk, Improving Outcomes. 2017 Sep 7;173:121.

[41]. Srivastava AK, Singh A, Yadav S, Mathur A. Endemic dental and skeletal fluorosis: Effects of high ground water fluoride in some North Indian Villages. 2011.

[42]. Pillai KS, Stanley VA. Implications of fluoride--an endless uncertainty. J Environ Biol. 2002 Jan;23(1):81-7.Pubmed PMID: 12617323.

[43]. Leelavathi L. Nicotine Replacement Therapy for Smoking Cessation-An Overview. Indian J Public Health Res Dev. 2019 Nov 1;10(11):3588.

[44]. Pratha AA, Prabakar J. Comparing the effect of Carbonated and energy drinks on salivary pH-In Vivo Randomized Controlled Trial. Res J Pharm Technol. 2019;12(10):4699-702.

[45]. Prabakar J, John J, Arumugham IM, Kumar RP, Sakthi DS. Comparing the Effectiveness of Probiotic, Green Tea, and Chlorhexidine- and Fluoride-containing Dentifrices on Oral Microbial Flora: A Double-blind, Randomized Clinical Trial. Contemp Clin Dent. 2018 Oct-Dec;9(4):560-569.Pubmed PMID: 31772463.

[46]. Mohapatra S, Kumar RP, Arumugham IM, Sakthi D, Jayashri P. Assessment of Microhardness of Enamel Carious Like Lesions After Treatment with Nova Min, Bio Min and Remin Pro Containing Toothpastes: An in Vitro Study. Indian J Public Health Res Dev . 2019 Oct 1;10(10):375. 
[47]. Kumar JV, Swango PA, Opima PN, Green EL. Dean's fluorosis index: an assessment of examiner reliability. J Public Health Dent. 2000 Mar;60(1):579.

[48]. Vijayashree Priyadharsini J. In silico validation of the non-antibiotic drugs acetaminophen and ibuprofen as antibacterial agents against red complex pathogens. J Periodontol. 2019 Dec;90(12):1441-1448.Pubmed PMID: 31257588 .

[49]. Pc J, Marimuthu T, Devadoss P, Kumar SM. Prevalence and measurement of anterior loop of the mandibular canal using CBCT: A cross sectional study. Clin Implant Dent Relat Res . 2018 Apr 6;20(4):531-4.

[50]. Ramesh A, Varghese S, Jayakumar ND, Malaiappan S. Comparative estimation of sulfiredoxin levels between chronic periodontitis and healthy patients - A case-control study. J Periodontol. 2018 Oct;89(10):1241-1248.Pubmed PMID: 30044495.

[51]. Ramadurai N, Gurunathan D, Samuel AV, Subramanian E, Rodrigues SJ. Effectiveness of $2 \%$ Articaine as an anesthetic agent in children: randomized controlled trial. Clin Oral Investig. 2019 Sep;23(9):3543-50.

[52]. Sridharan G, Ramani P, Patankar S, Vijayaraghavan R. Evaluation of salivary metabolomics in oral leukoplakia and oral squamous cell carcinoma. J Oral Pathol Med. 2019 Apr;48(4):299-306.

[53]. Ezhilarasan D, Apoorva VS, Ashok Vardhan N. Syzygium cumini extract induced reactive oxygen species-mediated apoptosis in human oral squamous carcinoma cells. J Oral Pathol Med. 2019 Feb;48(2):115-121.Pubmed
PMID: 30451321.

[54]. Mathew MG, Samuel SR, Soni AJ, Roopa KB. Evaluation of adhesion of Streptococcus mutans, plaque accumulation on zirconia and stainless steel crowns, and surrounding gingival inflammation in primary molars: randomized controlled trial. Clin Oral Investig. 2020 Sep;24(9):1-6.Pubmed PMID: 31955271

[55]. Samuel SR. Can 5-year-olds sensibly self-report the impact of developmental enamel defects on their quality of life? Int J Paediatr Dent. 2021 Mar;31(2):285-286.Pubmed PMID: 32416620.

[56]. R H, Ramani P, Ramanathan A, R JM, S G, Ramasubramanian A, et al. CYP2 C9 polymorphism among patients with oral squamous cell carcinoma and its role in altering the metabolism of benzo[a]pyrene. Oral Surg Oral Med Oral Pathol Oral Radiol. 2020 Sep;130(3):306-312.Pubmed PMID: 32773350 .

[57]. Chandrasekar R, Chandrasekhar S, Sundari KKS, Ravi P. Development and validation of a formula for objective assessment of cervical vertebral bone age. Prog Orthod. 2020 Oct 12;21(1):38.Pubmed PMID: 33043408.

[58]. Vijayashree Priyadharsini J, Smiline Girija AS, Paramasivam A. In silico analysis of virulence genes in an emerging dental pathogen A. baumannii and related species. Arch Oral Biol. 2018 Oct;94:93-98.Pubmed PMID: 30015217. 